\title{
Johnnie To Kei-Fung's Where a Good Man Goes
}

\author{
By Vicky Wong \\ Fall 1999 Issue of KINEMA
}

\section{REVERTING TOSOCIAL ORDER BY CONTAINMENT: JOHNNIE TO KEI-FUNG'S WHERE A GOOD MAN GOES}

The 1999 Hong Kong International Film Festival hailed the Hong Kong director Johnnie To Kei-Fung as a Director in Focus, featuring eleven of his films. The opening film of the Festival was his world premiere, Where a Good Man Goes, casting Lau Ching-wan and Ruby Wong, telling a story of the return of a prodigal son. The film, in short, evolves around a central theme "home". The author of this article suggests that this "home" is of the concept of a traditional home held by the Chinese, from ancient days to the present, and is also patriarchal. The film's story also tells of the "grand narratives" governing the order of the Chinese society since the early ages, which incidentally coincide with the Western view, that no evil can escape judgment and if a prodigal son returns, he will be accepted by all. Also, through the "home" and the grand narratives, people are then contained in the social order of a hegemony, which defines the orderliness or order of a society, and the male-female relationship.

One stormy night, Judy is mending the leaking roof helter-skelter, watched by her son who occasionally points out other leaks. Suddenly, they see a taxi stopping abruptly nearby. A man gets out of it, yelling and kicking at a door of the taxi. The taxi driver is furious. He comes out of the car and hits the man with a stick. Another taxi driver comes to the first driver's assistance but both are defeated. The son, while watching the fight, is urged by the mother not to watch it anymore. But fate has them involved in the man's life. The man, Michael, an ex-gang leader, has just been released from jail. He settles in the woman's place, the International Inn, a humble inn not deserving the name "international", which is going to be confiscated due to the large sum of a loan the woman, a widow, is not able to clear. And there begins an unusual love story which elaborates the concept of a Chinese "home" and the "grand narratives" that underlie it.

When the story begins, Judy is no ordinary woman. Not at all like a career woman nowadays, yet as a widow, she is hard pressed by life to manage the entire inn (which is also her home where she lives with her son and a maid) herself, though the business is slowly going bankrupt. She is tough and strong-minded, bearing all the burden of raising a family and the Chinese ethics that govern the society in which she lives. When she is summoned to bear witness to what has happened during that rainy night, out of righteousness, she tells the truth that it was the two taxi-drivers that started the fight, indicating Michael's involvement was only self-defence, ignoring the policeman's hint that she should tell otherwise.

Such a strong female character however, is not acceptable in a patriarchal world. This can be evidenced by analysing the concept of "home" held by the mobster Michael, a concept that has traditionally been supported by the male social-order Chinese society, which relegates women to silence, subordination, as weak and vulnerable characters who only serve the satisfaction and desire of men.

On the other hand, though Michael is of the dominant sex in the patriarchal world, he is also an outsider of the orderly world. He is violent, and his deeds are always destructive to the harmony and orderliness of the community. By extension, he is also the "other" of the society. And from the changing conceptualisation of what a "home" is like, Michael is, like Judy, finally contained in the orderly world.

\section{The Concept of "Home"}

The concept of a "home" changes after Michael and Judy's encounter. At first, he believes that "being a gangster, I'm prepared to treat the prison as my home", since he has been there for too many times and for too long. He even shows Judy's son the jail where he has spent a large portion of his life and is proud to disclose that he has participated in its renovation, which takes place once every three to five years. But then, as time evolves, changes take place.

Michael goes to his ex-girlfriend's company and demands some of his money back in order to save Judy's inn from being confiscated. In fact, this incident eventually turns out to be a "robbery" as the ex-girl friend's 
husband and one of her staff call the police. Judy rushes to the scene to persuade Michael to surrender. But Michael only says, "I've been in and out of the jail throughout these years and been into many inns as well. But there is no other place that makes me feel more comfortable than Room 206, International Inn. Perhaps it is because I feel like 'home' when I am there." And Judy replies, "It doesn't matter if there is the International Inn, nor does it matter where you are. As long as there is me, there is a home for you!"

However, how does the "home" in International Inn look like? A male-centred place, as can be observed from Judy's character traits and her interaction with Michael. Judy is submissive. When Michael arrives at International Inn, he yells at her for something to eat. Since the Inn does not provide catering services, he yells again. Judy then surrenders and cooks him some noodles. Then, he wants cigarettes. As the Inn does not sell cigarettes, he commands her to buy him some. In order not to let him disturb her other guests, she rushes to a store in heavy rain and gets him some. And then it becomes a habit that Michael eats together with the family - Judy, her son and the maid in the inn. Whether it is out of fear or out of love, it does not matter. The important thing is, the woman is submissive, and lives to serve.

Apart from this, what has Judy done that makes Michael feel at home? We could only see that she works very hard to clean his room and does the chores without a grudge, day in and day out. Every day, Michael makes the room a mess. But every night when he comes back, the room is dusted, the rubbish and cigarette ends are thrown out, the clothes are cleaned and ironed, the bed is made up, and cigarettes are never short. Judy is the inn-keeper and it is clearly her duty to serve. However, the extent that she is to serve so willingly far exceeds an inn-keeper's responsibility. The relegation of Judy to service and silence is a component of the "home" Michael perceives.

On the other hand, Judy is, among other things, a sex object. One night when Michael comes back, Judy has prepared a bowl of noodles for him. She enters his room to hang up his clothes. He gazes at her, silently, like a wild animal hunting for its prey. He comes near her, holds her hand, and kisses her. She is nervous, says no and struggles. As he is about to rape her, a knock on the door by Judy's son saves her. Though only a child, he is also a male, the dominant gender in the patriarchal world, and as such he, too has power over his mother.

What other things constitute a "home"? Perhaps it is the different roles of the couple as defined by the patriarchal world. At the beginning of the film, Judy is mending the leaking roof in vain, as water continues to drip into the house. In addition, images of the storm, the rain and the fighting scene, all combine to give the impression that the place is in a mess when it is being managed by Judy, a woman. On the contrary, there are other scenes that depict the orderliness of the inn when Michael mends the roof, fixes the electrical appliances, and paints the wall. Judy once says sternly to Michael's ex-girlfriend who comes to the inn to find out why Michael cares so much for his new girlfriend: "I'm only a simple woman and my life is simple. When the rooftop leaks, Michael mends it. When the shower doesn't work, Michael fixes it. I welcome Michael here."

It is obvious that the film has in many ways denoted the different roles assumed by the two sexes. Michael, being an ex-gang head, cannot gain any dignity outside of his "home". His former girlfriend took all his money away when he was in jail, refusing to give him a penny back. Meanwhile, Michael's former underworld pals form a gang of their own, denying him any real status or money. The only one who seems to hang out with him is just making use of him. Michael cannot even find a job, for lack of education and his background. He is, in fact, denied by society. The only comfort he can get is perhaps at home with Judy where he is strong, in control, the centre, and where the woman is only secondary, submissive, obedient and weak, and needs male protection.

\section{The "Grand Narratives"}

Professor Mary Klages of University of Colorado (1997) quotes the French theorist of postmodernism François Lyotard that "[t]otality, stability and order are maintained in modern societies through the means of "grand narratives" or "master narratives," which are stories a culture tells itself about its practices and beliefs." (Klages, 1977)

What defines and influences a culture is perhaps the hermeneutics of the canons and commentaries, which are in a dynamic process of being interpreted and reinterpreted (Zhang, 1999). Chinese communities have 
long been influenced by their early scholars, especially Confucius, and also Laozi. Their canons were studied not only as a means to enter government service, but also as the ways to lead one's life, manage a family, and deal with nature and people. As a result of this widespread influence on people or their world view, these may perhaps be referred to as Lyotard's "grand narratives" defining a culture.

Two items of such traditional beliefs of the Chinese on how to maintain and restore law and order can be derived from the story of "Where a Good Man Goes". Such a "maintenance and restoration" is not just a practical way to confine, award or punish people's behaviour but also a statement of certain beliefs that guide them.

(1) No one can escape the Judgment of Heaven. ("tien wang hui hui, shu er bu lou", from Laozi)

(2) It is a virtue to mend one's ways. ("chu er neng gai, shan mo da yan", from Confucius's lunyu)

Michael, as mentioned, is the "other" to the society. He is a mobster, violent, has no skills as to earn a living, and disturbs the order of the society. However, he is not the only "other". So is the the policeman who is always against Michael. As an officer of the law, he is supposed to be righteous, and to maintain law and order without reserve. However, since he has old scores to settle with Michael, he always finds faults with him and tries to use various schemes and tricks to trap him. In this sense, both of them can be considered as the "other" of the orderly society.

How do these two men end up in the film's story? As the first "grand narrative" goes, no one can escape the judgment of Heaven. So both are penalised. While Michael goes back to jail, the latter loses his police job. But this is not the end of the story. The cop has become a taxi-driver in the end. On the day when Michael is released from the jail, he accidentally? takes the cop-turned-driver's taxi. They exchange conversation in a light-hearted way. From their dialogue, their sharing of cigarettes and light, the free ride for Michael, one can tell that they have reconciled. Michael also says he is going to join Judy and her son in Portugal soon. This is indeed a happy ending, which transcends hatred and fatalism, applying the second "grand narrative" in question (i.e. it is always good to mend one's way) and signifying the restoration of harmony.

\section{Conclusion}

Denzin (1991) describes the hegemonic, realist reading of Blue Velvet (1986) as "[a] young man takes on evil in the world. He succumbs to this evil, but is ultimately redeemed, and finds his place back within the safe, sexual confines of married middle-class life, with a beautiful young bride." (p. 70) We can see a theme very similar to Johnnie To's Where a Good Man Goes here: the return (or in Denzin's term, the "redemption") of the prodigal son. Such a theme seems to be universal, with an aim to containing people in a social order defined by hegemonic views.

In Where a Good Man Goes, the "home" serves as a resting and healing place for the badly wounded mobster Michael. The home is a place of acceptance, forgiveness, warmth and love, which are always denied him outside the International Inn. "Home" is also a place where the "grand narratives" work in an exceptionally effective way.

Apart from the home remedy where evil turns virtuous, the roles of the male and female are defined in a patriarchal way. Whenever there are things that Judy does not approve of, such as Michael retaliating against the policeman for insulting the boy, she will either say something sternly or remain silent as a way of protest. In a patriarchal society, women are simply not expected to exert their power or express their views aggressively - at home or in public. Such family hierarchy is reflected in many mainstream films.

At the same time, in his 1991 essay on semiotics of film ("De-Evolutionizing the Feminine"), Jeff Major suggests that while the traditional way of viewing women is looking down on them, a more recent way is showing the nervousness in men themselves as a reaction to the threat of women in the contemporary world where their emancipation has reached a new height, threatening the traditional careers or roles of men. In Where a Good Man Goes, the strong female character Judy is perhaps a good example in depicting how women (and their threats to men) are contained within the family and how the family remedy (and also the grand narratives) can contain the potential disorder of a patriarchal society. 


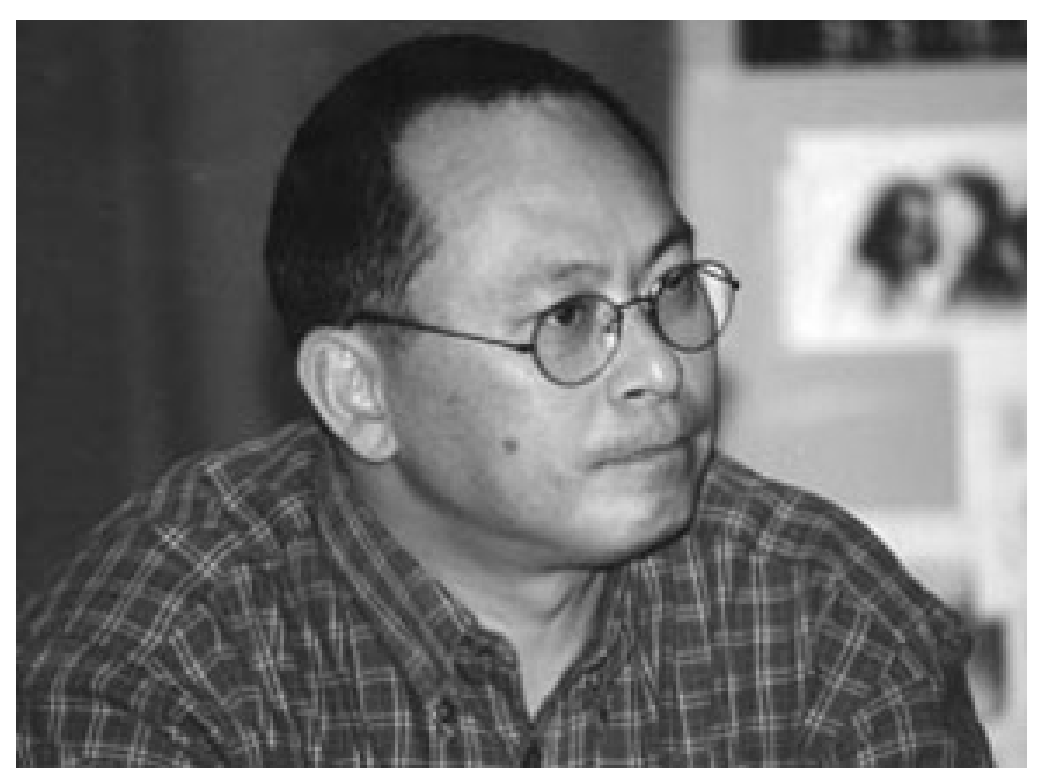

Figure 1: Director Johnnie To

\section{References}

Denzin, N. K. (1991). Images of Postmodern society: social theory and contemporary cinema. London: SAGE Publication.

Harvey, S. (1996). The absent family of film noir. In J Belton (Ed), Movies and mass culture. (pp 171-184). NJ: Zrutgers, The State University.

Klages, M. (1997). Postmodernism. http://www.colorado.edu/English/ENGL2012Klages/pomo.html. 10 August 1999.

Major, J. (1991). The semiotics of film - women and gorillas. http://www.jeffmajor.com/film/gorillas/index.html. 30 September 1999.

Zhang, L. (1999). Conference notes. At "Cannons and Commentaries": an International Conference on Hermeneutics, University of Hong Kong, 15-17 October 1999.

\section{Author Information}

Vicky WONG received her M.A. from the School of Oriental and African Studies, University of London and Hong Kong Baptist University. She developed her interest in film perception and communications while working at the Hong Kong International Film Festival secretariat as a translator. 